\title{
Pembelajaran Politik untuk Pemilih Pemula Melalui Media Sosial di Purwokerto - Jawa Tengah
}

\author{
Sri Pangestuti ${ }^{1}$, Ch. Herutomo ${ }^{2}$, dan S. Bekti Istiyanto ${ }^{3}$ \\ Fakultas sosial dan Ilmu Politik Universitas Jenderal Soedirman \\ J1. Prof. Dr. Boenyamin No. 993 Purwokerto - Indonesia \\ ${ }^{1}$ sripangestuti@yahoo.co.id; ${ }^{2}$ christoherutomo@gmail.com; ${ }^{3}$ bektiis@ yahoo.com
}

\begin{abstract}
Abstrak
Pembelajaran politik untuk pemilih pemula adalah subjek penelitian yang menarik. Pemilih pemula, merupakan segmen yang strategis untuk direkrut dalam kegiatan pemilihan umum baik dalam pemilihan Presiden, legislatif, dan kepala daerah di tahun politik 2019. Tujuan dari penelitian ini adalah untuk memahami bagaimana komunikasi melalui media mampu memberikan pengaruh untuk para remaja yang mempunyai rentang usia 17-21 tahun dalam menerima informasi politik sebagai bagian pembelajaran berpolitik. Asumsi dasar dari penelitian ini adalah bagaimana belajar berpolitik melalui media sosial untuk remaja merupakan fenomena yang menarik dan dapat memprediksi keberhasilan kegiatan politik praktis bagi pemilih pemula secara tepat. Penelitian ini menggunakan metode kualitatif dengan mengumpulkan data melalui wawancara mendalam dan focus of group discussion (FGD). Informan merupakan mahasiswa Jurusan Ilmu Komunikasi yang merupakan pemilih pemula. Karakteristik informan dibatasi dengan kriteria berumur dari 17-21 tahun, tahun 2019 merupakan partisipasi pertama dalam politk praktis seperti kegiatan pemilihan umum dan atau kepala daerah. Hasil dari studi ini: pembelajaran politk bagi pemilih pemula umumnya dipengaruhi oleh lingkungan terdekat di mana mereka tinggal; Strategi pembelajaran politik yang diperlukan untuk pemilih pemula dalam kegiatan politik praktis berjalan efektif menggunakan media sosial yang sesuai.
\end{abstract}

Kata kunci: pembelajaran. pemilih pemula, komunikasi politik, media

\begin{abstract}
Political learning for beginner voters is an interesting research subject. Beginner voters are a strategic segment to be recruited in general election activities both in the presidential, legislative and regional head elections in 2019 political year. The purpose of this study is to understand how communication through the media is able to influence teenagers who have an age range of $17-21$ years in receiving political information as part of political learning. The basic assumption of this study is how learning politics through social media for teenagers is an interesting phenomenon and can predict the success of practical political activities for beginner voters appropriately. This study uses qualitative methods by collecting data through in-depth interviews and focus of group discussion (FGD). Informants are Communication Department students who are beginner voters. Characteristics of informants are limited by criteria from the age of 17-21 years, 2019 is the first participation in practical politics such as general election activities and or regional heads. The results of this study: political learning for beginner voters is generally influenced by the closest environment in which they live; The political learning strategy needed for beginner voters in practical political activities runs effectively using appropriate social media.
\end{abstract}

Keywords: learning. beginner voters, political communication, media

Copyright @ 2018 Ikatan Sarjana Komunikasi Indonesia. All rights reserved

\section{PENDAHULUAN}

Sebagai negara dengan sistem politik demokrasi, Indonesia menggunakan pemilihan umum langsung. Ini merujuk kepada kondisi di mana semua warga yang telah memenuhi semua persyaratan diperbolehkan untuk memberikan suara dalam pemilihan. Ini sesuai dengan apa yang telah disebutkan 
dalam undang-undang pemilihan nomor 1 tahun 2014 yang mencakup pemilihan presiden, anggota dewan, gubernur, bupati-wakil bupati dan walikota-wakil walikota melalui pemilu. Ini adalah proses politik yang tidak jarang memanaskan konstelasi politik dan merupakan acara yang bertujuan untuk mendapatkan lebih banyak pendukung agar dapat memenangkan pemilihan, termasuk dari pemilih pemula. Dengan demikian, para pemilih pemula mengambil peran yang sangat penting di sini karena mempunyai suara yang sangat siginfikan untuk mempengaruhi hasil pemilihan umum.

Para pemilih pemula adalah salah satu sasaran strategis dalam kegiatan politik praktis, karena memiliki jumlah sekitar 35\% dari total konstituen (baranews.com). Mereka adalah warga negara dalam rentang usia 17-21 tahun yang baru memiliki pengalaman pertama mereka untuk menggunakan hak pilih mereka (rumahpemilu.org). Dalam usia ini, kepribadian remaja biasanya masih dalam kondisi yang labil dan dapat dengan mudah dipengaruhi. Mereka mudah bingung dan hanya sekedar menjadi pengikut dalam pengambilan keputusan, terutama keputusan politik. Dengan semua alasanalasan, ada begitu banyak pihak dari partai politik yang akan berjuang untuk mendapatkan suara mereka dan akan digunakan untuk memenangkan pemilihan umum di tahun politik 2019.

Dalam kenyataannya, para pemilih pemula merupakan sebuah potensi, baik untuk kegiatan politik praktis dan juga untuk kebutuhan masa depan politik di suatu negara. Oleh karena itu, harus ada proses pembelajaran, seperti sosialisasi yang tepat untuk mereka. Dengan sosialisasi, diharapkan bahwa para pemilih pemula akan menyadari pentingnya untuk menggunakan hak-hak suara mereka dalam proses demokrasi. Dengan demikian hal ini juga akan membantu secara tidak langsung pemerintah seperti untuk membuat arah kebijakan dan pembangunan bangsa. Menjadi sangat penting bila pemahaman tentang kesadaran politik untuk pemilih pemula harus diwujudkan melalui proses pembelajaran politik yang dapat diakses dengan mudah oleh para pemilih pemula secara langsung dan massif.

Kehidupan remaja berhubungan dengan media komunikasi berbasis internet. Salah satunya adalah media sosial, yang telah menjadi media komunikasi dan interaksi yang dapat memberikan informasi dan pengetahuan dalam cara yang cepat, besar-besaran. Jenis media sosial yang biasanya digunakan oleh para pemilih pemula seperti Facebook, Instagram, Line, BBM dan WhatsApp. Biasanya dalam berkomunikasi melalui media sosial, para remaja menggunakan bahasa yang tidak terlalu kaku atau formal. Secara tidak langsung itu akan menciptakan komunikasi yang akrab, santai dan langsung di antara penggnanya.

Komunikasi yang akrab dan santai serta sesuai kebutuhan remaja pastilah akan diperhatikan oleh para partai politik, kandidat pemimpin daerah dan para pendukungnya/tim suksesnya untuk melakukan transformasi informasi serta memilih strategi penyebaran informasi yang intens kepada para remaja. Secara khusus mereka akan mempertimbangkan isi media agar para pemilih pemula bersedia untuk diarahkan ke kepentingan atau partai politik mereka.

\section{KERANGKA TEORITIS}

Proses pembelajaran politik untuk pemilih pemula adalah benar-benar sesuatu yang dibutuhkan dewasa ini. Secara formal proses belajar di sini didefinisikan sebagai proses interaksi antara siswa dan pengajar dengan sumber belajar dalam lingkungan tertentu belajar (Sulthan, 2010). Proses belajar adalah bantuan yang diberikan oleh pengajar sehingga akan ada suatu proses untuk memperoleh pengetahuan, keterampilan, dan penguasaan karakter yang mampu membentuk sikap dan iman siswa (https://id.wikipedia.org/wiki/Pembelajaran). Dalam kata lain, belajar adalah proses untuk membantu siswa untuk belajar dengan baik termasuk dalam permasalahan politik dan pemilihan umum, terutama di negara demokrasi dengan sistem pemilihan langsung seperti Indonesia.

Dengan menerapkan teori Pembelajaran Klasik, media sosial dapat mengambil peran dalam proses pembelajaran, kemudian membentuk publik pendapat, membentuk keyakinan kepada para kandidat dan memberikan harapan bagi konstituen. Komunikasi politik akan bekerja di tingkat dalam menjelaskan ide-ide, pendapat, konsep dan hal-hal lain yang berkaitan dengan usaha untuk mendapatkan dan mempertahankan kekuasaan (Alfian, 1978). Ini berlanjut dengan strategi 
komunikasi yang efektif yang kemudian akan membentuk gambaran politik tertentu (Fachri Ali, 2005:54).

Para pemilih pemula yang merupakan mahasiswa dengan rentang usia 17-21 tahun, adalah segmen yang unik dan bisa memberikan kejutan, khususnya dalam potensi jumlah. Mereka unik karena perilaku mereka identik dengan antusiasme yang tinggi, cenderung lebih rasional, mereka haus untuk mendapatkan perubahan dan memiliki lebih sedikit polusi pragmatisme. Pilihan politik mereka tidak dipengaruhi oleh motivasi ideologi dan berupaya dengan konteks dinamika lingkungan lokal. Namun para pemilih pemula biasanya mudah terpengaruh oleh kepentingan tertentu, terutama oleh orang-orang terdekat seperti keluarga, kerabat dan teman-teman. Selain itu, media massa juga memberikan pengaruh terhadap pilihan pemilih pemula. Ini bisa dilihat dalam televisi, banner, poster, brosur dan lain-lain.

Masing-masing persaingan untuk mendapatkan suara dari pemilih pemula melalui media sosial akan memanaskan kondisi pemiliha presiden, legislatif tingkat nasional, provinsi dan kabupaten. Karena itu akan menjadi wajar bila proses pembelajaran politik melalui komunikasi politik yang dicontohkan oleh para pelaku politik praktis di Indonesia seringkali berjalan kurang adil. Hal ini bisa dikarenakan adanya upaya-upaya untuk melakukan kecurangan-kecurangan agar bisa mempengaruhi para pemilih. Sering konsep ini disebut dengan istilah kampanye hitam dan politik uang.

Dengan kondisi para remaja sebagai pemilih pemula dan menggunakan media sosial secara besar-besaran. Maka menjadi tidak heran bila telepon genggam tidak dapat dipisahkan dari mereka dan akan dibawa setiap saat (Istiyanto, 2015). Inilah yang dimungkinkan untuk mampu membentuk partisipasi politik yang dekat atau jauh dari apa yang diinginkan melalui media sosial yang selalu digunakan remaja sebagai pemilih pemula untuk mendapatkan informasi tentang politik dan pemilihan umum di tahun politik 2019.

Sementara itu, penggunaan teknologi elektronik semakin memungkinkan semua penggunanya berhubungan dengan cepat. Karenanya kehadiran media baru juga mengalami perkembangan signifikan. Bermunculan wahana media sosial seperti twitter, facebook, path, line, whatsapp, dan sebagainya. Media ini dikenal sebagai media sosial karena memberi peluang setiap orang melakukan jejaringan sosial dan berbagi informasi. Pesan informasi melalui media sosial dengan jejaring internet ini disusun dan dikemas sedemikian rupa agar tersampaikan secara lebih efektif (Sudarmanti dan Yusuf, 2016).

Media sosial adalah media untuk interaksi sosial, menggunakan teknik komunikasi yang sangat mudah diakses. Media sosial kini sudah menjadi bagian kehidupan sehari-hari pengguna internet di Indonesia karena situs yang paling sering dikunjungi. Pengguna internet pada umumnya menggunakan waktu terbanyak online untuk berkomunikasi melalui media sosial, seperti Facebook, Twitter, Ask.fm dan lain-lain.

Media sosial juga dapat memfasilitasi perubahan. Media sosial adalah sebuah media online, dengan para penggunanya bisa dengan mudah berpartisipasi, berbagi, dan menciptakan isi meliputi blog, jejaring sosial, wiki, forum dan dunia virtual. Blog, jejaring sosial dan wiki merupakan bentuk media sosial yang paling umum digunakan oleh masyarakat di seluruh dunia. Pendapat lain mengatakan bahwa media sosial adalah media online yang mendukung interaksi sosial dan mengubah komunikasi menjadi dialog interaktif. Jejaring sosial merupakan situs dimana setiap orang bisa membuat web page pribadi, kemudian terhubung dengan teman-teman untuk berbagi informasi dan berkomunikasi.

\section{METODE PENELITIAN}

Penelitian ini menggunakan metode kualititaif dengan analisis deskriptif. Penelitian ini dengan demikian tidak melakukan uji hipotetis. Moleong (2000: 4) mendefinisikan metode kualitatif sebagai prosedur penelitian yang memberikan hasil sebagai data deskriptif, baik sebagai pernyataan tertulis atau lisan dari orang-orang dan juga perilaku mereka. Semua tahapan penelitian ini dilakukan 
untuk memperoleh gambaran fenomena sosial untuk menjelaskan situasi dan kejadian dengan katakata tertulis.

Ada dua data yang diperoleh, yaitu data primer dan sekunder berdasarkan metode purposive sampling. Total informan adalah 8 individu dengan rentang usia 17-21 tahun, yang terdiri dari masiswa Jurusan Ilmu Komunikasi. Untuk metode analisis dilakukan secara interaktif dengan tiga cara, yaitu reduksi data, penyajian data dan penarikan kesimpulan (Miles dan Huberman, 2014).

\section{HASIL PENELITIAN}

Hasil awal dari penelitian ini menunjukkan fenomena sosial dari proses pembelajaran politik bagi pemilih pemula pada umumnya dipengaruhi oleh; pertama, lingkungan terdekat seperti orang tua dan keluarga inti; kedua, dari kelompok sebaya di sekolah atau perguruan tinggi; dan ketiga, dari dampak media sosial yang mereka gunakan.

Dari ketiga domain proses pembelajaran politik remaja ini, 8 informan menyatakan bahwa media sosial seperti WhatsApp, Facebook, Twitter, Instagram, dan Line termasuk telah memberikan pembelajaran politik yang intensif. Setiap gagasan dan konsep yang ditransaksikan dalam bentuk informasi dan pengetahuan politik, direspons dengan baik oleh para pemilih pemula.

Komunikator adalah pihak yang merencanakan skenario untuk mensukseskan proses pembelajaran dan kemudian melakukannya selangkah demi selangkah dengan strategi berikut; pengkondisian penonton (pemula pemilih) dilakukan oleh ide-ide yang menyegarkan, konsep yang menggembirakan untuk mendapatkan masa depan yang lebih baik. Para kandidat yang muncul dalam profil foto, baik dalam foto secara individu atau grup. Dalam bahasa umum, informasi yang cepat dan stabil tentang pengenalan calon atau pelaku politik praktis telah disosialisasikan secara efektif kepada para khalayaknya.

Proses pembelajaran komunikasi politik yang dilakukan melalui media sosial ini telah memunculkan strategi yang diprediksi akan mendapatkan umpan balik seperti yang diharapkan. Mulai dari membangun keyakinan pemilih pemula hingga menciptakan simpati untuk memilih calon tertentu. Termasuk juga dengan pengkondisian nilai-nilai yang sesuai dengan harapan pemilih, janjijanji pasca kemenangan, dan lain-lain.

Pada langkah ini, pemahaman, perilaku, dan perubahan sikap terjadi pada para pemilih pemula sebagai target, yang dibuktikan dengan adanya komentar dukungan atau penolakan. Prosesnya berjalan cukup lama, terutama terjadi sebelum kampanye hingga penutupan kampanye. Tanpa disadari, perilaku pemilih pemula telah dibentuk, apakah akan tetap untuk memilih atau berpaling ke kandidat yang lain, semua dapat diprediksi. Ada juga tiga emosi yang bisa disimpulkan, yaitu kemarahan, ketakutan, dan cinta/rasa suka atas para kandidat atau partai politik yang dimunculkan media untuk mereka.

Dari 8 informan, yang merupakan mahasiswa merupakan para pemilih pemula yang tingkat emosinya belum stabil dan lebih sering memberikan reaksi secara emosional atas segala sesuatu. Meskipun demikian para informan mahasiswa ini cukup rasional. Mereka juga mampu membuat sebuah keputusan politik yang tidak didasarkan pada kemarahan, ketakutan dan kebencian saja. Meskipun keputusan mereka bisa salah, namun ini menjadi poin yang penting dalam proses pembelajaran politik bagi mereka. Kondisi ini dikarenakan mereka dapat memodifikasi keputusan mereka dengan hal-hal lain, seperti informasi dan pengetahuan lainnya yang sesuai.

Berdasarkan kondisi yang disebutkan di atas, pada tahap ini media sosial mulai melakukan penguatan. Realisasi adalah membentuk perilaku imitasi karena proses adaptasi bekerja secara progresif (Skiner, 1971). Paparan informasi dan pengetahuan terus-menerus dapat memberikan efek yang besar bagi pembelajar. Ini merupakan hasil dari suatu proses pembelajaran, dimana seorang individu mampu memiliki keputusan politik yang tepat. Proses tersebut akan berjalan dengan baik, meskipun seringkali mereka saat membuat keputusan juga memiliki risiko yang salah.

Dalam prosesnya, para pemilih pemula seringkali masih bingung dan dengan demikian keputusan politik mereka akan cenderung mengikuti sumber-sumber lain yang ditawarkan media sosial dan kurang tidak bisa berpikir secara rasional. Mereka akan terkena dampak informasi secara 
terus-menerus dalam intensitas tinggi, contoh meskipun dalam kampanye politik yang dilakukan dalam waktu seminggu oleh para kandidat atau partai politik mereka mendapatkan informasi yang dibutuhkan, akan tetapi mereka juga terkena sumber-sumber informasi yang lain di hampir setiap waktu saat mereka mengakses informasi, seperti melalui iklan media sosial dalam bentuk foto, gambar, atau bahkan pernyataan verbal.

Pada Tahap Partisipasi, belajar, menurut Bandura (1997) adalah proses, metode, perbuatan yang dilakukan secara terus menerus untuk membawa perubahan baik perilaku atau pengetahuan. Sementara partisipasi adalah tindakan atau perilaku untuk terlibat dan atau melakukan sesuatu. Partisipasi politik yang didefinisikan dalam penelitian ini bukanlah pada bentuk seperti memberikan suara dalam pemilihan tapi bagaimana membentuk perilaku yang relatif tetap dengan penegasan dan mendukung sikap politik tertentu melalui media sosial, seperti misalnya bagaimana mereka memberikan suaranya yang dilakukan dalam petisi di website sepert change.org.

Berdasarkan hasil wawancara mendalam, informan penelitian ini dapat dipetakan bahwa para infroman ini dapat dibagi sebagai partisipan yang aktif. Di sini mereka lebih banyak jumlahnya dibandingkan mereka yang menjadi partisipan pasif dalam mengikuti sebuah perkembangan politik kekinian. Partisipasi aktif didefinisikan sebagai anggota kelompok yang membuat keputusan politik tertentu, sementara partisipasi pasif didefinisikan sebagai hanya dengan menjadi pembaca berita politik, tetapi tidak membuat sebuah tindakan tertentu.

Partisipasi pasif tidak akan membuat para pemilih pemula belajar komunikasi politik secara nyata yang dapat ditemukan dengan mudah di media sosial. Di kondisi yang lain, para pemilih pemula sebagai remaja adalah warga-negara potensial yang akan melanjutkan kepemimpinan untuk masa depan negara. Inilah kedua kondisi informan dalam melakukan aktivitas pembelajaran berpolitik yang didapatkan dari hasil penelitian ini.

\section{KESIMPULAN}

Sebagai kesimpulan, dapat ditemukan bahwa; pertama, proses pembelajaran politik bagi para pemilih pemula umumnya dipengaruhi oleh lingkungan terdekat di sekitar mereka. Kedua, strategi pembelajaran politik yang diperlukan untuk pemilih pemula agar mau terlibat aktif dalam kegiatan politik praktis (melalui pemilu atau pilkada) salahsatunya melalui media sosial yang merupakan media komunikasi yang dapat digunakan secara massif dan mudah oleh para pemilih pemula. Dengan demikian, pelaku politik baik semestinya dapat mengisi media sosial dengan informasi dan pengetahuan tentang politik secara baik, melalui pesan dan bahasa yang sesuai dan berjalan secara adil, cerdas, dan bertanggung jawab.

\section{Daftar Pustaka}

Ali, Fahcri. 2005. Politik Pencitraan Parpol PengaruhiPersepsi Publik. Jakarta: Gramedia. Alfian, M. Alfan. 1978. Pemikiran dan Perubahan Politik Indonesia. Jakarta: Gramedia.

Bandura. 1977. Social Learning Theory. Upper Sadle River, NJ: Prentice Hall.

Istiyanto, Bekti. 2015. Penggunaan Teknologi Komunikasi dan Perubahan Sosial (Studi Kasus Penggunaan Handphone Bagi Anak-Anak di Kelurahan Bobosan Purwokerto Utara). Jakarta: Jurnal Komunikasi ISKI Vol 1(1): 58-63

Matthew B. Miles dan Michael Huberman. 2014. Analisis Data Kualitatif buku sumber MetodeMetode Baru. Jakarta: Universitas Indonesia

Moleong, Lexy J. 2000. Metode Penelitian Kualitatif, Cetak Ke-12. Bandung: PT Remaja Rosdakarya.

Skinner, BF. 1971. Contigencies of Reinforcement. East Norwalk: Appleton

Sudarmanti, Rini \& Yusuf, Kurniawaty. 2016. Pemanfaatan Media Sosial sebagai Media Komunikasi Ibu dan Anak Remaja. The 3rd Indonesia Media Research Awards \& Summit (IMRAS). Jakarta: Serikat Perusahaan Pers.

Sulthan, Muhammad. 2010. Komunikasi Pemasaran Politik. Bandung: Unpad Press.

Susanto, AB. 2004. Politik dan Pemilu dalam Perspektif Pemasaran, Artikel Harian Umum. 
Website:

https://id.wikipedia.org/wiki/Pembelajaran accessed on 1 September 2015

https:// rumahpemilu.org accessed on 1 September 2015 